\title{
Acute appendicitis during pregnancy: case series of 20 pregnant women
}

\author{
İlker Murat Arer, M.D., ${ }^{1}$ Songül Alemdaroğlu, M.D., ${ }^{2}$ Hasan Yeşilağaç, M.D., ${ }^{3}$ Hakan Yabanoğlu, M.D. ${ }^{1}$
}

${ }^{1}$ Department of General Surgery, Başkent University Adana Teaching and Research Center, Adana-Turkey

2Department of Obstetrics and Gynecology, Başkent University Adana Teaching and Research Center, Adana-Turkey

${ }^{3}$ Department of Emergency Medicine, Başkent University Adana Teaching and Research Center, Adana-Turkey

\begin{abstract}
BACKGROUND: Acute appendicitis (AA) is the most common cause of acute abdomen during pregnancy. Most of the signs of appendicitis are also found during normal pregnancy period, however, and diagnosis of appendicitis during pregnancy remains challenging. The aim of the current study was to report our clinical experience of AA during pregnancy and investigate optimal management of this difficult situation.
\end{abstract}

METHODS: Records of 20 pregnant women with diagnosis of AA who underwent appendectomy between 2005 and 2015 were included in this study. Data were collected retrospectively. Patients were evaluated according to age, signs and symptoms, gestational age, physical findings, serum white blood cell count, ultrasound (US) findings, pathology reports, surgical technique, operation time, and complications.

RESULTS: Of 20 patients, 16 (80\%) underwent open appendectomy and 4 (20\%) underwent laparoscopic appendectomy. Mean age of patients was $29.6 \pm 5.6$ years. Most common symptom was abdominal pain (95\%). Six (30\%) patients were in first trimester, $9(45 \%)$ patients were in second trimester and $5(25 \%)$ patients in were in third trimester. US findings consistent with AA were found in 12 (60\%) patients. Negative appendectomy rate was $30 \%$. Maternal complication was seen in only I (5\%) patient. No fetal complication was observed.

CONCLUSION: Accurate diagnosis and prompt surgical treatment of AA in pregnant women should be performed due to high rates of maternal and fetal complications.

Keywords: Acute appendicitis; appendectomy; pregnancy.

\section{INTRODUCTION}

Acute appendicitis (AA) is the most common cause of acute abdomen during pregnancy and accounts for $25 \%$ of non-obstetric surgery during pregnancy with an incidence of $1 / 500$ to I/2000 of all pregnancies. ${ }^{[1,2]}$ Diagnosis of appendicitis during pregnancy remains challenging. Physiological mild leukocytosis seen in pregnant women, change in location of appendix and low sensitivity rates of ultrasound (US) imaging cause

Address for correspondence: Illker Murat Arer, M.D.

Dadaloğlu Mah., Başkent Üniversitesi Adana Uygulama ve Araştırma Merkezi, Genel Cerrahi Anabilim Dalı, Yüreğir, Adana, Turkey Tel: +90 322 - 3272727 E-mail: igy1981@yahoo.com

Qucik Response Code

Ulus Travma Acil Cerrahi Derg

2016;22(6):545-548

doi: $10.5505 /$ tjtes.2016.58458

Copyright 2016

TJTES delay in diagnosis of appendicitis. ${ }^{[3-5]}$ Therefore, complications occur more frequently during pregnancy than in non-pregnant women. ${ }^{[6]}$ Although US is the most commonly and easily performed diagnostic tool for AA in pregnancy, recently magnetic resonance imaging (MRI) has been reported to be superior, with sensitivity and specificity rates of $96.8 \%$ and $99.2 \%$ respectively. ${ }^{[7,8]}$ Since most of the signs of appendicitis are also found during normal pregnancy period, decisions about surgery become more difficult with these patients. Surgery is unavoidable, but there are stıll questions about which technique to be used for appendectomy, laparoscopic or open surgery. Laparoscopic surgery for pregnant women has been found to be safe and accurate. ${ }^{[9]}$ However, while laparoscopic appendectomy during pregnancy is associated with low rate of intraoperative complications in all trimesters, it is associated with significantly higher rate of fetal loss compared to open appendectomy. ${ }^{[10]}$

The aim of the current study was to report our clinical experience with AA during pregnancy and investigate optimal management of this difficult situation. 


\section{MATERIALS AND METHODS}

Our study consisted of records of 20 pregnant women with AA diagnosis who underwent appendectomy between September 2005 and September 2015 at Başkent University Adana Teaching and Research Center. Data were collected retrospectively from software database and patient files. Patients were evaluated according to age, signs and symptoms, gestational age, physical findings, serum white blood cell (WBC) count, US findings, pathology reports, surgical technique, operation time, and complications.

\section{Statistical Analysis}

SPSS software was used for statistical analysis (Version 17.0; SPSS Inc., Chicago, IL, USA). If continuous variables were normal, they were described as mean \pm standard deviation ( $p>0.05$, Kolmogorov-Smirnov test; $n<30$, Shapiro-Wilk test), and if the continuous variables were not normal, they were described as median.

\section{RESULTS}

Twenty pregnant women underwent appendectomy during 10 -year period of study. Of those, $16(80 \%)$ underwent open appendectomy and 4 (20\%) underwent laparoscopic appendectomy. Mean age of the patients was $29.6 \pm 5.6$ years. Most

Table I. Demographic characteristics of patients $(n=20)$

\begin{tabular}{|c|c|c|c|}
\hline & $\mathbf{n}$ & $\%$ & Mean \pm SD \\
\hline Age (Years) & & & $29.6 \pm 5.6$ \\
\hline \multicolumn{4}{|l|}{ Symptoms } \\
\hline Abdominal pain & 19 & 95 & \\
\hline Nausea & 1 & 5 & \\
\hline \multicolumn{4}{|l|}{ Physical finding } \\
\hline RLQP & 7 & 35 & \\
\hline RLQP+rebound & 11 & 55 & \\
\hline RLQP+rebound+defense & 2 & 10 & \\
\hline \multicolumn{4}{|l|}{ Surgical technique } \\
\hline Laparoscopic & 16 & 80 & \\
\hline Open & 4 & 20 & \\
\hline \multicolumn{4}{|l|}{ Gestational age } \\
\hline I $^{\text {st }}$ trimester & 6 & 30 & \\
\hline $2^{\text {nd }}$ trimester & 9 & 45 & \\
\hline $3^{\text {rd }}$ trimester & 5 & 25 & \\
\hline White blood cell count $\left(\times 10^{3} / \mu \mathrm{L}\right)$ & & & $14.2 \pm 5.9$ \\
\hline Operation time (minutes) & & & $45.45 \pm 21.03$ \\
\hline Negative appendectomy & 6 & 30 & \\
\hline Complication (SSI) & I & 5 & \\
\hline
\end{tabular}

SD: Standard deviation; RLQP: Right lower quadrant pain, SSI: surgical site infection. common symptom, abdominal pain, was seen in 19 (95\%) patients, and nausea was reported in I (5\%) patient. In physical examination right lower quadrant pain (RLQP) was present in 7 (35\%), both RLQP and rebound were present in II (55\%), and RLQP with rebound and defense was present in $2(10 \%)$ patients. At time of diagnosis, 6 (30\%) patients were in first trimester, $9(45 \%)$ patients in second trimester and 5 (25\%) patients in third trimester. US findings consistent with AA were found in $12(60 \%)$ patients. Average WBC count of patients was $14.2 \pm 5.9 \times 10^{3} / \mu \mathrm{L}$ (range: $3-30 \times 10^{3} / \mu \mathrm{L}$ ). Mean operation time was $45.45 \pm 21.03$ minutes. Permanent pathology report of AA was found in $6(30 \%)$ cases. Surgical site infection as postoperative complication was observed in only I patient (5\%) with perforated appendicitis. No fetal complication was observed (Table I).

\section{DISCUSSION}

Non-obstetric surgical intervention is performed on nearly $2 \%$ of all pregnant women annually worldwide. ${ }^{[1,12]}$ The most commonly performed non-obstetric operation (44\%) on pregnant women is appendectomy. ${ }^{[13]}$ Diagnosis of commonly encountered signs of appendicitis is challenging due to physiological changes that occur during pregnancy. Mild leukocytosis and abdominal tenderness are common findings in pregnant women. Thus, delay in diagnosis can lead to perforation of the appendix. Perforation rate has also been found to be associated with advanced gestational age and delayed admission to the hospital. ${ }^{[14]}$ Therefore, prompt diagnosis and appropriate therapy are crucial for pregnant patients with acute abdomen in order to prevent fetal and maternal mortality and morbidity. ${ }^{[15]}$ In a study of 52 pregnant women who underwent appendectomy, perforation of the appendix was found to be the only predictive factor for maternal morbidity, and if interval between onset of symptoms and operation exceeds 20 hours, perforation is almost inevitable. ${ }^{[16]}$

Although diagnosis of appendicitis is clinical, fetal growth makes it difficult by changing the location of the appendix. RLQ tenderness elevates superiorly in the second and third trimesters. ${ }^{[17]}$ Imaging studies are recommended in order to reduce delays in surgery due to diagnostic uncertainty and to reduce rate of negative appendectomies. ${ }^{[18]}$ US is typically the first radiological modality used to aid in diagnosis of appendicitis is US. However, US imaging has limitations even in nonpregnant population, and it is difficult to visualize appendix or secondary findings of appendicitis during pregnancy. US is reported to be valuable in evaluation of appendicitis in pregnant women, especially in the first trimester, but non-visualization rate of US is high, particularly in advanced pregnancy. ${ }^{\left[{ }^{[1]}\right]}$ In the present study, though most of the patients $(70 \%)$ were in second and third trimesters, contrary to literature findings, US indicated AA with $40 \%$ accuracy in these patients. We believe that in experienced hands, US is a very useful diagnostic tool for AA in pregnancy, regardless of trimester. Another radiological modality, MRI, is also used for diagnosis 
of appendicitis in pregnant women due to high rate of appendix non-visualization in US scanning. MRI has been reported to have sensitivity and specificity rates as high as $91.7 \%$ and $95.3 \%$, respectively, ${ }^{[20]}$ and can be used when surgical exploration is considered.

Negative appendectomy rates during pregnancy have been reported as between $3 \%$ and $23 \% .{ }^{[2,22]}$ Terzi et al. found rate of $13 \%{ }^{[14]}$ and Miloudi et al. reported negative appendectomy rate of $3.4 \% .{ }^{[23]}$ Present study finding of $30 \%$ rate is higher than literature findings, but may be explained by inability to perform MRI or presence of physical findings that indicated urgent exploration.

Although treatment for appendicitis is surgery, technique to be used for the procedure continues to be a subject of investigation. Should we perform open or laparoscopic appendicitis? Which one is feasible? Some authors encourage laparoscopic approach, ${ }^{[24]}$ whereas some have found open appendectomy to be safer. ${ }^{[10]}$ In a hospital-based retrospective review of 65 pregnant women with suspected appendicitis, laparoscopic appendectomy was found to be a safe, feasible, and efficacious approach. ${ }^{[25]}$ Laparoscopy offers shorter hospital stay and reduced risk of thromboembolic events. ${ }^{[26]}$ Some authors state that even in perforated cases, laparoscopy appears safe in pregnant patients. ${ }^{[27]}$ There are also some limitations to use of laparoscopic appendectomy such as instance of diffuse peritonitis, advanced pregnancy with markedly enlarged uterus, or lack of experience of the surgeon or operating team.

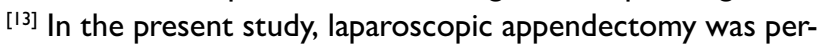
formed in $20 \%$ of all patients without any complication; thus, we also believe that it is a safe and feasible approach for pregnant women with appendicitis.

Since perforated appendicitis is known to be associated with high rate of maternal and fetal morbidity and mortality, rapid and accurate diagnosis of appendicitis is particularly critical in pregnant patients. Risk of premature onset of labor has been reported to be between $8 \%$ and $33 \%{ }^{[28,29]}$ Fetal loss has been reported as between $0 \%$ and $12.1 \% .^{[10,30]}$ There was no case of fetal demise in this current study. This can be explained by the low rate of perforation (5\%) in our study, found only in I patient.

\section{Conclusion}

Although diagnosis remains challenging, urgent surgical treatment of AA in pregnant women should be performed due to high rates of maternal and fetal complications. Radiological modalities such as US or MRI should be performed in cases of unclear diagnosis.

\section{Acknowledgments}

This study did not receive any specific funding or grants.

Conflict of interest: None declared.

\section{REFERENCES}

1. Andersen B, Nielsen TF. Appendicitis in pregnancy: diagnosis, management and complications. Acta Obstet Gynecol Scand 1999;78:758-62.

2. Long SS, Long C, Lai H, Macura KJ. Imaging strategies for right lower quadrant pain in pregnancy. AJR Am J Roentgenol 2011;196:4-12.

3. Abbasi N, Patenaude V, Abenhaim HA. Evaluation of obstetrical and fetal outcomes in pregnancies complicated by acute appendicitis. Arch Gynecol Obstet 2014;290:661-7. Crossref

4. Spalluto LB, Woodfield CA, DeBenedectis CM, Lazarus E. MR imaging evaluation of abdominal pain during pregnancy: appendicitis and other nonobstetric causes. Radiographics 2012;32:317-34. Crossref

5. Pitkin RM, Witte DL. Platelet and leukocyte counts in pregnancy.JAMA 1979;242:2696-8. Crossref

6. Dietrich CS 3rd, Hill CC, Hueman M. Surgical diseases presenting in pregnancy. Surg Clin North Am 2008;88:403-19. Crossref

7. Greenhalgh R, Punwani S, Taylor SA. Is MRI routinely indicated in pregnant patients with suspected appendicitis after equivocal ultrasound examination? Abdom Imaging 2008;33:21-5. Crossref

8. Burke LM, Bashir MR, Miller FH, Siegelman ES, Brown M, Alobaidy $\mathrm{M}$, et al. Magnetic resonance imaging of acute appendicitis in pregnancy: a 5-year multi-institutional study. Am J Obstet Gynecol 2015. Crossref

9. Rizzo AG. Laparoscopic surgery in pregnancy: long-term follow-up. J Laparoendosc Adv Surg Tech A 2003;13:11-5. Crossref

10. Walsh CA, Tang T, Walsh SR. Laparoscopic versus open appendicectomy in pregnancy: a systematic review. Int J Surg 2008;6:339-44.

11. Cheek TG, Baird E. Anesthesia for nonobstetric surgery: maternal and fetal considerations. Clin Obstet Gynecol 2009;52:535-45. Crossref

12. Gilo NB, Amini D, Landy HJ. Appendicitis and cholecystitis in pregnancy. Clin Obstet Gynecol 2009;52:586-96. Crossref

13. Juhasz-Böss I, Solomayer E, Strik M, Raspé C. Abdominal surgery in pregnancy--an interdisciplinary challenge. Dtsch Arztebl Int 2014;111:465-72.

14. Terzi A, Yildiz F, Vural M, Coban S, Cece H, Kaya M. A case series of 46 appendectomies during pregnancy. Wien Klin Wochenschr 2010;122:686-90. Crossref

15. Unal A, Sayharman SE, Ozel L, Unal E, Aka N, Titiz I, et al. Acute abdomen in pregnancy requiring surgical management: a 20-case series. Eur J Obstet Gynecol Reprod Biol 2011;159:87-90. Crossref

16. Yilmaz HG, Akgun Y, Bac B, Celik Y. Acute appendicitis in pregnancy-risk factors associated with principal outcomes: a case control study. Int J Surg 2007;5:192-7. Crossref

17. Pates JA, Avendanio TC, Zaretsky MV, McIntire DD, Twickler DM. The appendix in pregnancy: confirming historical observations with a contemporary modality. Obstet Gynecol 2009;114:805-8. Crossref

18. de Franca Neto AH, do Amorim MM, Nóbrega BM. Acute appendicitis in pregnancy: literature review. Rev Assoc Med Bras 2015;61:170-7.

19. Drake FT, Kotagal M, Simmons LE, Parr Z, Dighe MK, Flum DR. Single institution and statewide performance of ultrasound in diagnosing appendicitis in pregnancy. J Matern Fetal Neonatal Med 2015;28:727-33.

20. Theilen LH, Mellnick VM, Longman RE, Tuuli MG, Odibo AO, Macones GA, et al. Utility of magnetic resonance imaging for suspected appendicitis in pregnant women. Am J Obstet Gynecol 2015;212:345. e1-6. Crossref

21. McGee TM. Acute appendicitis in pregnancy. Aust N Z J Obstet Gynaecol 1989;29:378-85. Crossref

22. McGory ML, Zingmond DS, Tillou A, Hiatt JR, Ko CY, Cryer HM. Negative appendectomy in pregnant women is associated with a substan- 
tial risk of fetal loss. J Am Coll Surg 2007;205:534-40. Crossref

23. Miloudi N, Brahem M, Ben Abid S, Mzoughi Z, Arfa N, Tahar Khalfallah M. Acute appendicitis in pregnancy: specific features of diagnosis and treatment. J Visc Surg 2012;149:275-9. Crossref

24. Barnes SL, Shane MD, Schoemann MB, Bernard AC, Boulanger BR. Laparoscopic appendectomy after 30 weeks pregnancy: report of two cases and description of technique. Am Surg 2004;70:733-6.

25. Sadot E, Telem DA, Arora M, Butala P, Nguyen SQ, Divino CM. Laparoscopy: a safe approach to appendicitis during pregnancy. Surg Endosc 2010;24:383-9. Crossref

26. Pearl J, Price R, Richardson W, Fanelli R; Society of American Gastrointestinal Endoscopic Surgeons. Guidelines for diagnosis, treatment, and use of laparoscopy for surgical problems during pregnancy. Surg Endosc
2011;25:3479-92. Crossref

27. Cox TC, Huntington CR, Blair LJ, Prasad T, Lincourt AE, Augenstein VA, et al. Laparoscopic appendectomy and cholecystectomy versus open: a study in 1999 pregnant patients. Surg Endosc 2016;30:593-602.

28. Kazim SF, Pal KM. Appendicitis in pregnancy: experience of thirty-eight patients diagnosed and managed at a tertiary care hospital in Karachi. Int J Surg 2009;7:365-7. Crossref

29. Aggenbach L, Zeeman GG, Cantineau AE, Gordijn SJ, Hofker HS. Impact of appendicitis during pregnancy: no delay in accurate diagnosis and treatment. Int J Surg 2015;15:84-9. Crossref

30. Kapan S, Bozkurt MA, Turhan AN, Gönenç M, Alış H. Management of acute appendicitis in pregnancy. Ulus Travma Acil Cerrahi Derg 2013;19:20-4. Crossref

\section{ORIJINAL ÇALIŞMA - ÖZET}

\section{Gebelikte akut apandisit: 20 hamile kadın olgu çalışması}

\section{Dr. İlker Murat Arer, ${ }^{1}$ Dr. Songül Alemdaroğlu, ${ }^{2}$ Dr. Hasan Yeşilağaç, ${ }^{3}$ Dr. Hakan Yabanoğlu ${ }^{1}$}

1Başkent Üniversitesi Adana Uygulama ve Araştırma Merkezi, Genel Cerrahi Anabilim Dalı, Adana

${ }^{2}$ Başkent Üniversitesi Adana Uygulama ve Araştırma Merkezi, Kadın Hastalıkları ve Doğum Anabilim Dalı, Adana

${ }^{3}$ Başkent Üniversitesi Adana Uygulama ve Araştırma Merkezi, Acil Tıp Anabilim Dalı, Adana

AMAÇ: Hamilelikteki en sık akut karın nedeni akut apandisittir. Apandisit bulgularının çoğu normal hamlilelik sürecinde olabileceğinden, gebelerde akut apandisit tanısı zordur. Çalışmamızın amacı, hamilelik döneminde karşılaştığımız akut apandisit olgularını aktarmak ve bu zor durumda uygun tedaviyi araştırmak.

GEREÇ VE YÖNTEM: 2005-20I5 yılları arasında akut apandisit nedeniyle ameliyat edilen 20 hamile kadın hasta çalışmaya dahil edildi. Veriler geriye dönük olarak toplandı. Hastalar, yaş, bulgu ve semptomlar, gestasyon yaşı, fiziksel inceleme bulguları, ameliyat süresi ve komplikasyon açısından incelendi.

BULGULAR: On altı (\%80) hastaya açık, dört (\%20) hastaya laparoskopik apendektomi yapıldı. Ortalama yaş $29.6 \pm 5.6$ yıldı. En sık semptom karın ağrısıydı (\%95). Altı (\%30) hasta I. üç ayda, dokuz (\%45) hasta 2. üç ayda ve beş (\%25) hasta son üç ayda idi. On iki (\%60) hastada ultrasonografide akut apandisit bulgusu saptandı. Negatif apendektomi oranı \%30'du. Sadece bir (\%5) hastada maternal komplikasyon saptandı. Hiç fetal komplikasyon saptanmadı.

TARTIŞMA: Yüksek maternal ve fetal komplikasyon oranlarından dolayı, gebelerde akut apandisitin doğru tanısı ve hızı cerrahi tedavisi yapılmalıdır. Anahtar sözcükler: Akut apandisit; apendektomi; gebelik.

Ulus Travma Acil Cerrahi Derg 2016;22(6):545-548 doi: 10.5505/tjtes.2016.58458 